\title{
Impact of late glacial climate variations on stratification and trophic state of the meromictic lake Längsee (Austria): validation of a conceptual model by multi proxy studies
}

\author{
Roland SCHMIDT*, Roland PSENNER ${ }^{1)}$, Jens MÜLLER ${ }^{2)}$, Peter INDINGER and Christian KAMENIK \\ Institute of Limnology, Mondseestraße 9, A-5310 Mondsee, Austria \\ ${ }^{1)}$ Institute of Zoology and Limnmology, University of Innsbruck, Technikerstraße 25, A-6020 Innsbruck, Austria \\ ${ }^{2)}$ Technische Universität München, Lehrstuhl für Allgemeine, Angewandte und Ingenieurgeologie, Arcisstraße 21, D - 80290 \\ München, Germany \\ *e-mail corresponding author: roland.schmidt@oeaw.ac.at
}

\begin{abstract}
Selected pigments, diatoms and diatom-inferred phosphorus (Di-TP) concentrations of a late glacial sediment core section of the meromictic Längsee, Austria, were compared with tephra- and varve-dated pollen stratigraphic and geochemical results. A conceptual model was adopted for Längsee and evaluated using multi proxy data. During the unforested late Pleniglacial, a holomictic lake stage with low primary productivity prevailed. Subsequent to the Lateglacial Betula expansion, at about 14,300 cal. y BP, okenone and isorenieratene, pigments from purple and green sulphur bacteria, indicate the onset of anoxic conditions in the hypolimnion. The formation of laminae coincides with this anoxic, meromictic period with high, though fluctuating, amounts of okenone that persisted throughout the Lateglacial interstadial. The occurrence of unlaminated sediment sections of allochthonous origin, and concurrent low concentrations of okenone, were related to cool and wet climate fluctuations during this period, probably coupled with a complete mixing of the water column. Two of these oscillations of the Lateglacial interstadial have been correlated tentatively with the Aegelsee and Gerzensee oscillations in the Alps. The latter climate fluctuation divides a period of enhanced anoxia and primary productivity, correlated with the Alleröd chronozone. Continental climate conditions were assumed to be the main driving forces for meromictic stability during Alleröd times. In addition, calcite dissolution due to severe hypolimnetic anoxia, appear to have supported meromictic stability. Increased pigment concentrations, which are in contrast to low diatom-inferred total phosphorus (Di$T P$ ), indicate the formation of a productive metalimnion during this period, probably due to a clear-water phase (low catchment erosion), increased temperatures, and a steep gradient between the phosphorus enriched hypolimnion and the oligotrophic epilimnion. Meltwater impacts from an extended snow-cover and a summer temperature decline, together with climate instability, are assumed to be the main reasons for the lowering of the anoxic level during the following, climatically heterogeneous, Younger Dryas. Meromictic stability was re-established with the termination of the Younger Dryas. The sequence of key pigments, Di-TP, calcite, siliciclastics, and organic carbon, seem to be in accordance with the assumptions of the conceptual model.
\end{abstract}

Key words: late glacial, meromixis, trophy, diatoms, pigments

\section{INTRODUCTION}

Late glacial climate variability offers an excellent opportunity to evaluate climate impacts on lake stratification and trophic level of meromictic Längsee. The term meromictic lake, based on investigations of Längsee in Carinthia, was first used by Findenegg (1937) for stratified lakes without completely seasonal turn-over, resulting in an anoxic hypo(monimo)limnion. Längsee (548 $\mathrm{m}$ a.s.1.; $\left.46^{\circ} 45^{\prime} 45^{\prime \prime} \mathrm{N} / 14^{\circ} 25^{\prime} 10^{\prime \prime} \mathrm{E}\right)$ is a small $(0.75$ $\mathrm{km}^{2}$ ), $21.4 \mathrm{~m}$ deep, lake which is situated in the Carinthian lowland, Austria (Fig. 1). Findenegg (1935, 1947, 1953) proposed that Längsee is a dynamic type of meromixis. During recent times, the depth of oxygen depletion has varied from $15 \mathrm{~m}$ (1934) to $12 \mathrm{~m}$ (1991), and in an extreme case (winter 1983/84) was close to the lake surface (Sampl et al. 1992). The early onset of an extended ice-cover during 1983/84 resulted in enhanced anoxia (Honsig-Erlenburg \& Schulz 1989; Honsig-Erlenburg 1995b).
Several publications dealed with the development of meromixis in Längsee. Frey (1955) assumed the onset of sapropel deposition as the approximate start of meromixis. Based upon the disappearance of ostracods, and the occurrence of Chaoborus, Löffler (1973, 1975) pointed out that hypolimnetic oxygen depletion started much earlier than the deposition of sapropel, namely during late glacial. Löffler (1975) has shown that the onset of meromixis in Austrian lakes is closely related to climate warming during the late glacial or early Holocene. The late glacial onset of meromixis in Längsee was verified by Harmsworth (1984) based on geochemical data. According to Schultze (1988/89), the concentrations of total carotenoids increased slightly below a tephra layer, which he tentatively related to the Laacher See tephra (LST), and culminated during early Holocene. A multi proxy study of a long core (including diatoms and diatom phosphorus inference) was performed by Schmidt et al. (1998). Different anoxic levels with respect to climate changes during the late glacial 
and Holocene underlined the dynamic type of meromixis, as proposed by Findenegg (1947). Pollen and geochemical analyses, with a higher time resolution from a late glacial core section of Längsee, were presented by Schmidt et al. (2002).

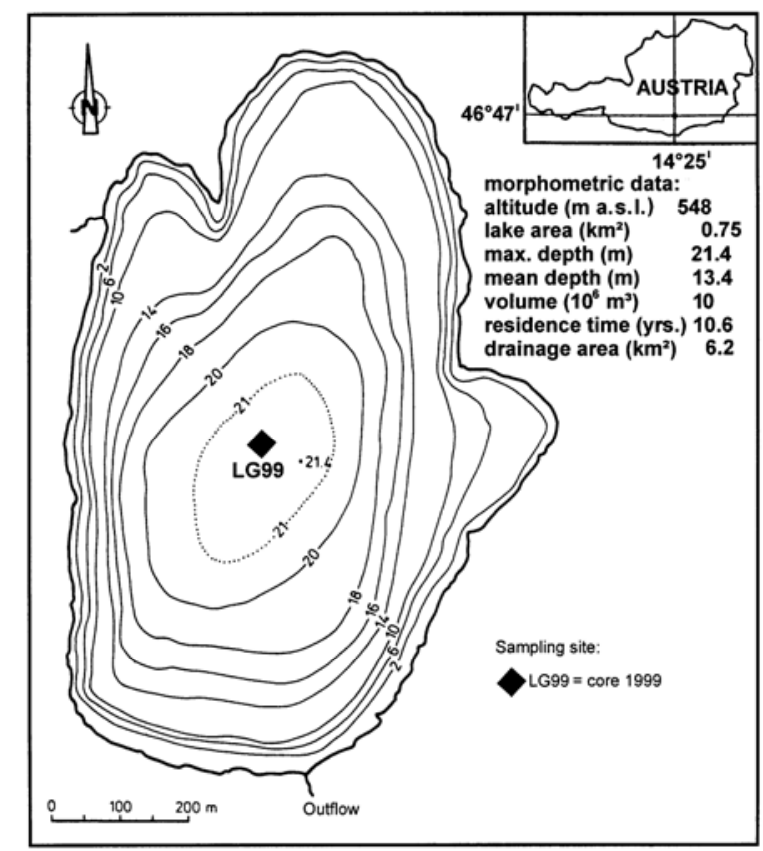

Fig. 1. Location of Längsee, bathymetric map (Schulz \& Kanz 1984) with sampling site (LG99), and morphometric data.

In the present study, the pollen and geochemical results from Schmidt et al. (2002) were combined with pigment and diatom analyses, and diatom-inferred phosphorus data based on an Alpine diatom/phosphorus calibration set (Wunsam 1995; Wunsam \& Schmidt 1995; Wunsam et al. 1995; Battarbee et al. 2001). Pigment analysis focused on indicator pigments of anoxic conditions, such as the bacteriochlorophylls okenone and isorenieratene, which are specific for purple and green sulphur bacteria (Züllig 1985; Hodgson et al. 1998; Lami et al. 2000). The multi proxy results were compared to a conceptual model of meromixis adopted for Längsee.

\section{CHRONOSTRATIGRAPHY}

The regional chronostratigraphy was established by Schmidt et al. (2002) by laminae counts and the presence of a tephra layer, which was correlated to the Neapolitan Yellow Tuff (NYT), dated at 14,120 cal. BP. The pollen record indicated three main pollen zones: A zone rich in non-arboreal pollen (NAP) around 14,300 cal. y BP is followed by a birch-rich pollen zone, and at ca 13,900 cal. y BP by a pine-dominated pollen zone. The pine-dominated pollenzone was divided into two Pinus sylvestris-rich subzones. The younger one is ac- companied by sparse pollen occurrences of deciduous trees. It probably correlates with the Alleröd chronozone sensu Litt et al. (2001). The subsequent Younger Dryas biozone is characterized only by a slight increase in NAP and dominated by pine with visible variations only in pine pollen types.

Differentiation of pine pollen types allowed Schmidt et al. (2002) to distinguish three minor fluctuations during the Lateglacial interstadial. Two of these oscillations tentatively have been correlated with the Aegelsee (Lg-FL1) and Gerzensee (Lg-FL3) oscillations in Switzerland (see Lotter et al. 1992) as well as with vegetation changes in NW Germany. Lg-FL2 has no parallel up to now in the Alps.

\section{CONCEPTUAL MODEL OF MEROMIXIS IN LÄNGSEE}

Based on the limnology of Längsee (Findenegg 1935, 1947, 1953; Berger 1973; Schulz et al. 1998; Honsig-Erlenburg \& Schulz 1989; Sampl et al. 1992, 2001; Honsig-Erlenburg 1995a; Honsig-Erlenburg 2000; and unpublished data of the Kärtner Institut für Seenforschung, Klagenfurt), and on past palaeolimnological records (Frey 1955, 1956; Löffler 1973, 1975; Harmsworth 1984; Schultze 1988/89; Schmidt et al. 1998), we developed the following conceptual model:

We assume that extended winter-ice cover, coupled with warm, dry summers, mainly contributed to the meromictic stability in Längsee. The importance of winter ice-cover for meromixis in Längsee is supported by remarkable changes in the oxygen budget of Längsee which occurred during the interval 1996 to 2000 (Sampl et al. 2001). During the warm winters 1997 and 1999, and during early spring 1998 the lake was completely mixed. During cold winter periods from 1984 to 1987 the lake was regularly ice-covered, resulting in stronger anoxia (see Fig. 2).

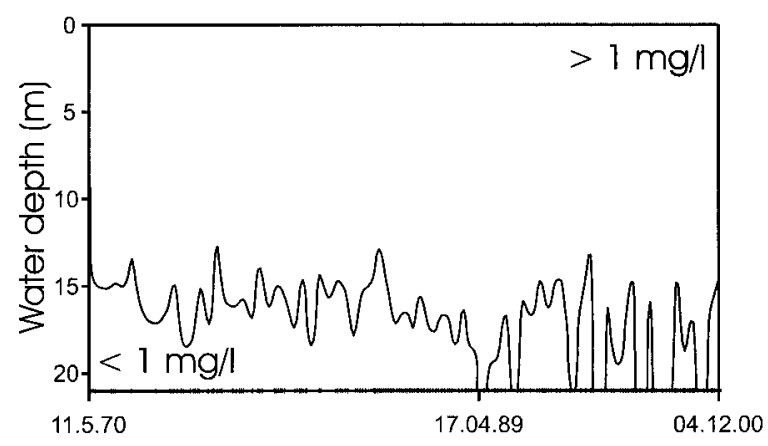

Fig. 2. Interpolated $\mathrm{O}_{2}$-isoplethe of Längsee during the periods 1970-2000 (interpolation by krigging; unpublished data of the Kärntner Institut für Seenforschung, Klagenfurt). Tick marks indicate sampling intervals.

During warm periods, a more dense terrestrial vegetation is supposed to reduce the input of inorganic 
nutrients from erosion and weathering, but to enhance the concentration of dissolved organic matter (DOM), thus reducing the penetration depth of UV radiation (as shown by Sommaruga \& Psenner 1997): the pelagic zone becomes a more hospitable environment for phytoplankton. The DOM input is especially enhanced by the expansion of broad-leafed trees. Warmer summers, a probable decrease in lake level and flushing rates, will lead to longer and more stable stratification periods and, consequently, to anoxic conditions in the hypolimnion, followed by the reductive release of phosphorus and iron. The release of ions under anoxic conditions and the dissolution of calcite, favoured by the increase in $\mathrm{pCO}_{2}$, stabilize the stratification by enhancing the density of hypolimnetic waters, which may lead to meromixis. At the same time, calcite precipitation from the epilimnion and input from allochthonous sources is expected to decrease because of epilimnetic oligotrophy and a drier climate. Although the lake becomes supposedly more oligotrophic at the beginning of the meromictic period - mainly because of a reduced flux of phosporus-rich deep water into the epilimnion - accumulation of dissolved phosphorus in the hypolimnion will lead, on the long term, to an increase in the trophic level of the lake with the progression of meromictic conditions. Increased lake transparency, higher water temperatures, and a phosphorus gradient favour the formation of a productive metalimnion.

The present Längsee indicates an inverse phosphorus water profile. The mean annual total phosphorus concentration in the epilimnion during 1984 to 1987 was about $10 \mu \mathrm{g}^{-1}$, reaching a maximum of $29 \mu \mathrm{g} \mathrm{l}^{-1}$ at $12 \mathrm{~m}$ water depth (Sampl et al. 1992). The close relationship between total phosphorus (TP) in the hypolimnion and anoxic conditions characterized the years 1998 to 1999; TP increased markedly with the increase in anoxy during 1999, compared to a lower level during 1998 (Sampl et al. 2001).

When the lake reverts to holomixis in a cold and wet climate, dissolved phosphorus and reduced iron accumulated in the monimolimnion will be dispersed in the whole water column. Thus, a TP peak with subsequent phosphorus precipitation is expected immediately after the onset of the holomictic state. Calcite accumulation will be enhanced by redeposition of littoral calcite, because of the increase in water level and/or higher flushing rates. Cool and wet periods with enhanced physical weathering and higher flushing rates, as well as strong meltwater episods, will result in periodic inputs of rock debris and inorganic nutrients from the catchment. These impacts are expected to increase when vegetation becomes less dense during unfavourable climatic periods. The shift in redox potential (iron oxydation) and the availability of minerogenic particles will then lead to a precipitation and adsorption of phosphorus. Deepwater sulphur bacteria will decrease in numbers or dissappear. The formation of laminated sediments is pre- vented by the oxygenation of the whole water column and the reduced pelagic production, a consequence of higher minerogenic turbidity and the lack of dissolved phosphorus.

When we apply this conceptual model to both the meromictic and holomictic stages of Längsee, as well as the switching between those conditions, we can summarize the impacts on significant parameters in a schematic diagram (Fig. 3).

\section{METHODS}

\subsection{Coring}

The sediment core was taken during February 1999 with a modified Kullenberg piston sampler (Schultze \& Niederreiter 1990). The coring equipment consisted of liners of $2 \mathrm{~m}$ length and $5.58 \mathrm{~cm}$ inside diameter, placed within a steel chamber, and a hydraulic rubber-closing system to avoid sediment losses. Coring was performed from the ice cover at the lake's maximum depth (21.4 $\mathrm{m})$. For subsampling, the plastic tubes containing the sediment were cut with a saw and divided into halves with the use of two thin metal plates. Subsample intervals were $1 \mathrm{~cm}$ for pigments, and $2 \mathrm{~cm}$ for diatoms.

\subsection{Diatom analysis}

Diatom samples were prepared with $30 \% \mathrm{H}_{2} \mathrm{O}_{2}$ and $10 \% \mathrm{HCl}$ according to Battarbee (1986). Aliquot-evaporated suspensions were embedded in Naphrax. At least 500 valves were counted in the light microscope (Leitz Diaplan) using phase contrast oil immersion objectives (N.A. 1.32) with a magnification of $1250 \times$. Taxonomy and selection of morphotypes of Cyclotella taxa followed Wunsam et al. (1995). To infer total phosphorus from the fossil diatom assemblages (Di-TP), transfer functions based on weigthed averaging (WA) with tolerance downweighting and classical deshrinking, adapted by Wunsam (1995) and Wunsam et al. (1995) from a training set of 86 Alpine and pre-alpine lakes were used. For the diatom-inferred TP, the program WACALIB (Line et al. 1994), version 3.4, was used.

\subsection{Pigments analysis}

The core was transported and stored at $4^{\circ} \mathrm{C}$ in darkness to minimize pigment degradation. The core was opened 10 days after the collection in a $4{ }^{\circ} \mathrm{C}$ chamber under dim light. Pigment analysis was done on 1-2 g fresh sediment transferred to polypropylene tubes, snap frozen using liquid nitrogen, and stored at $-22{ }^{\circ} \mathrm{C}$ until extraction. Extraction was done with 90\% HPLC-grade Acetone (Mantoura \& Llewellyn 1983) for about 15 hours at $4{ }^{\circ} \mathrm{C}$. After centrifugation, the extract was measured with a UV-VIS-Spectrophotometer (UV-1202 Shimadzu) at $450 \mathrm{~nm}$ for crude carotenoids, and at 665 and $750 \mathrm{~nm}$ for total chlorophylls (Züllig 1989). The separation of the single carotenoid was obtained by 45 minutes adapted gradient program (Wright et al. 1991) 


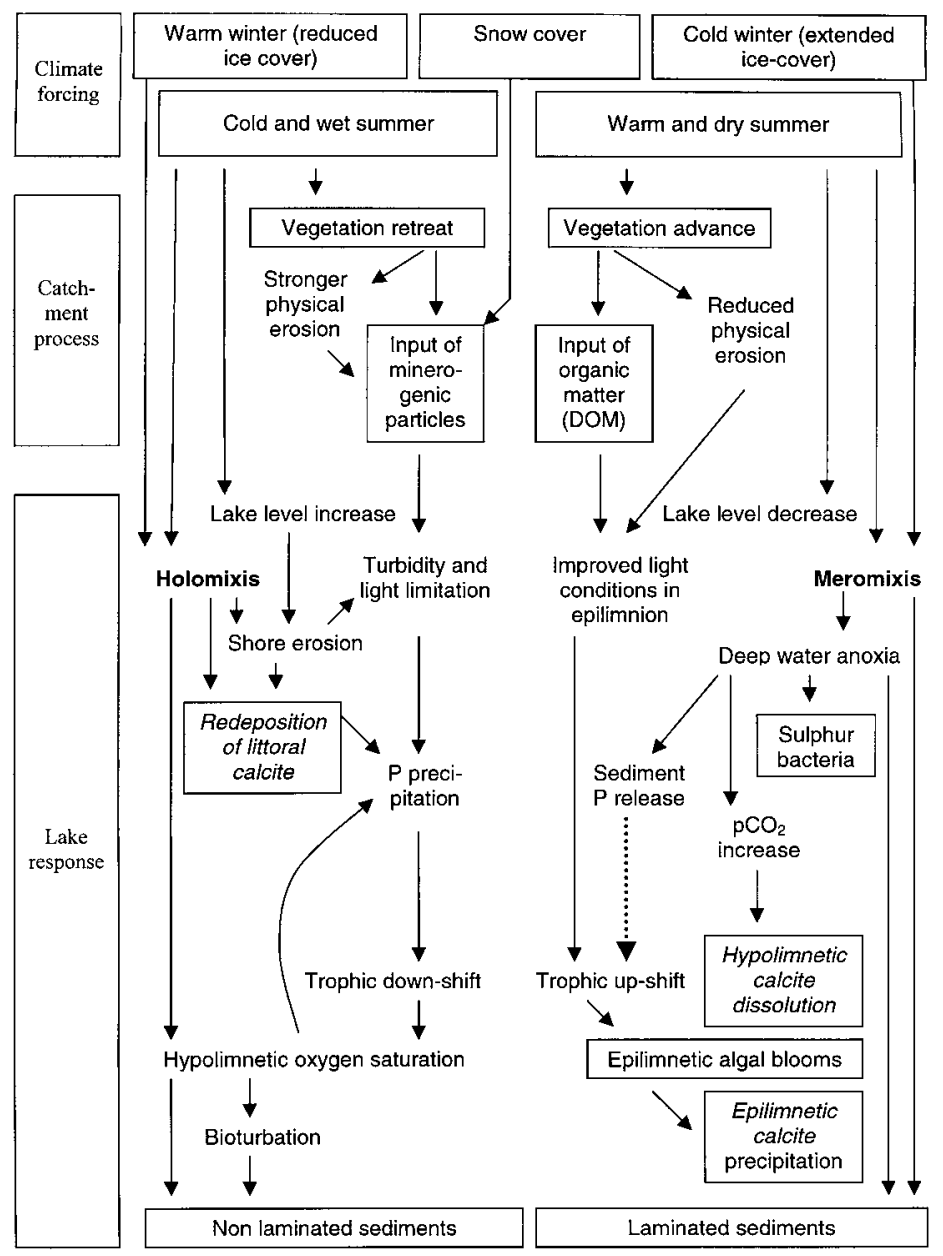

Fig. 3. Conceptual model of catchment-lake interactions during climate change at Längsee. Boxes in the flux diagram relate to biological and sedimentological parameters, which, in addition to diatom-inferred total phosphorus, were reconstructed by the multi proxy studies (pollen, $\mathrm{C}_{\text {org }}$, siliciclastics, calcite, key-pigments, laminae).

HPLC system (HP-1100) equipped with an HP LiChroCart Supersphere RP-18 250-4 (250 mm, 4 mm, $4 \mu \mathrm{m}$, non-encapped, reversed phase) column (Schmid \& Stich 1995). Methanol, acetonitrile, ethyl acetate ( $>99.9 \%$, Rotisolv HPLC-grade) were used as solvents; ammonium acetate (Merck) as ion-paring reagent. Carotenoids and chlorophylls were identified with the use of pigment standards, algae and bacterial cultures, as well as literature data (Züllig 1985; Borrego \& Garcia-Gil 1994; Jeffrey et al. 1997; Hodgson et al. 1998). Pigment concentrations were reported as nanogram (ng) per gram organic matter $\left(\mathrm{LOI} 550^{\circ} \mathrm{C}\right)$.

\section{RESULTS}

\subsection{Diatoms}

\subsubsection{Diatom stratigraphy}

Five main diatom zones (Fig. 4) were distinguished: The lowermost zone 1, from 388 to $373 \mathrm{~cm}$, is dominated by small, benthic Fragilaria spp. High abundance of Campylodiscus noricus (1/1) are followed by a slight increase of Cyclotella taxa (see zone 2), and by a peak of Fragilaria construens var. venter (maximum 72\%). In the subsequent zone 2, from 373 to $361 \mathrm{~cm}$, the $C y$ clotella comensis complex, C. distinguenda var. unipunctata, and C. cyclopuncta, increased in relative frequence. A marked peak of Cyclotella praetermissa/quadrijuncta (at maximum 60\%) divides this zone. Cyclotella ocellata increased during the upper part (2/2) and dominated during zone 3 (361 to $353 \mathrm{~cm}$; maximum 74\%). Cyclotella aff. ocellata increased at the transition to the following zone 4. During zone 4, from 353 to 345 $\mathrm{cm}$, Stephanodiscus alpinus increased, as did Cyclotella comensis (morphotype 1) (maximum 50\%). Cyclotella aff. plitvicensis ocurred in low numbers. During the following zone 5, from 345 to $320 \mathrm{~cm}$, C. ocellata and $F$. construens var. venter increased again in abundance, however with less abundances than during the zones 1 and 3 (C. ocellata). A peak of Stephanodiscus minutulus in the middle of the zone $(5 / 2 ; 30 \%)$, the increased im- 


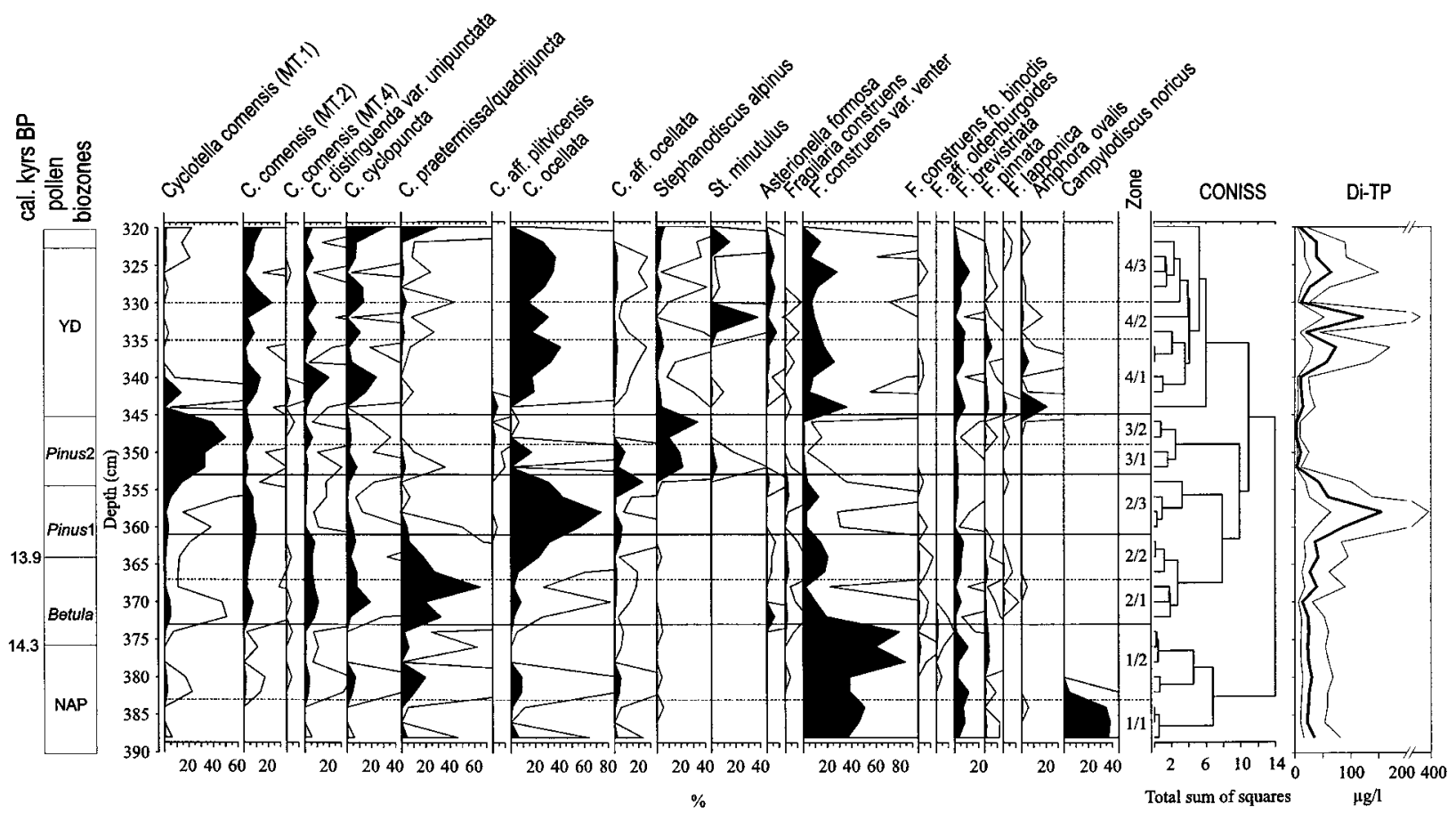

Fig. 4. Percentage diagram of selected diatoms of the Längsee core LG99, diatom zones, diatom-inferred phosphorus (Di-TP) with estimated standard errors of prediction, and main pollen zones ( $\mathrm{YD}=$ Younger Dryas). Calibrated years according to the tephra- and laminae-based chronostratigraphy (Schmidt et al. 2002) are added.

portance of Amphora ovalis in the lower part, and the expansion of $C$. cyclopuncta and C. praetermissa/quadrijuncta towards top, divide this zone 5 .

\subsubsection{Diatom inferred total phosphorus}

Diatoms with unknown TP-optima accounted for $27 \%$ on average and $34 \%$ at maximum $(385 \mathrm{~cm})$. Di-TP levels $<15 \mu \mathrm{g} \mathrm{l}^{-1}$ were inferred for the section 352 to 340 $\mathrm{cm}$, and for $320 \mathrm{~cm}$. The samples 387 to 367 , and 328 were within 15 to $30 \mu \mathrm{g} \mathrm{l}^{-1}$. Peaks of Di-TP $>100 \mu \mathrm{g} \mathrm{l}^{-1}$ occurred at 357 and $332 \mathrm{~cm}$ (Fig. 4).

\subsubsection{Pigment stratigraphy}

The pigment concentrations (Fig. 5a) divide the core section into the following zones: The zone below 373 $\mathrm{cm}$ with less than $0.1 \mathrm{ng}$ of total carotenoids per gram organic matter (OM); the zone from 373 to $344 \mathrm{~cm}$ with higher $\left(0.5-5 \mathrm{ng} \mathrm{g}^{-1} \mathrm{OM}\right)$, although fluctuating, values of okenone and isorenieratene; lower concentration of both occur between 365 to $363 \mathrm{~cm}$, at $353 \mathrm{~cm}$, and at $347 \mathrm{~cm}$; marked peaks of lutein, canthaxanthin, and zeaxanthin occur between 352 to $350 \mathrm{~cm}$, and at $345 \mathrm{~cm}$. The zone from 344 to $325 \mathrm{~cm}$, with low pigment concentrations, showed a slight pigment increase in the middle of the zone $\left(1-2.5 \mathrm{ng} \mathrm{g}^{-1} \mathrm{OM}\right)$. At the top ( 325 to $320 \mathrm{~cm})$, all pigments increased again. The okenone/isorenieratene ratio showed higher values between 370 to $360 \mathrm{~cm}$ than between 360 to $320 \mathrm{~cm}$. The latter, however, was interupted by three 3 less prominent peaks $(343,333,328 \mathrm{~cm})$. The pigments are compared with the geochemical data in figure $5 \mathrm{~b}$, modified from Schmidt et al. (2002).

\section{DISCUSSION}

\subsection{Impacts of long-term climate changes on lake stratification and trophy}

\subsubsection{Late Pleniglacial ( $>375 \mathrm{~cm},>14,300$ cal. y BP)}

The diatom assemblages of the unlaminated minerogenic sediments of the Late Pleniglacial are dominated by Fragilaria spp. According to Wunsam (1995) they are more frequent in cold water lakes, resulting in inferred summer surface water temperatures below $12{ }^{\circ} \mathrm{C}$ for this biozone (Schmidt et al. 1998). An average DiTP of about $20 \mu^{-1}$ was inferred. However, higher abundances of small, benthic Fragilaria taxa might have been caused by other environmental parameters than nutrients, e.g. ice-cover (e.g. Smol 1988; Douglas \& Smol 1999). Therefore, TP-inference of Fragilariarich layers should be approaced with caution (Bennion et al. 2001). Low total organic carbon $\left(\mathrm{C}_{\text {org }}\right)$ together with low pigment concentrations indicate low primary production. Low summer surface water temperatures coupled with minerogenic matter originating from catchment erosion may have been the reasons for low primary production. Cool summers and enhanced meltwater fluxes from the catchment may have prevented 
(a)

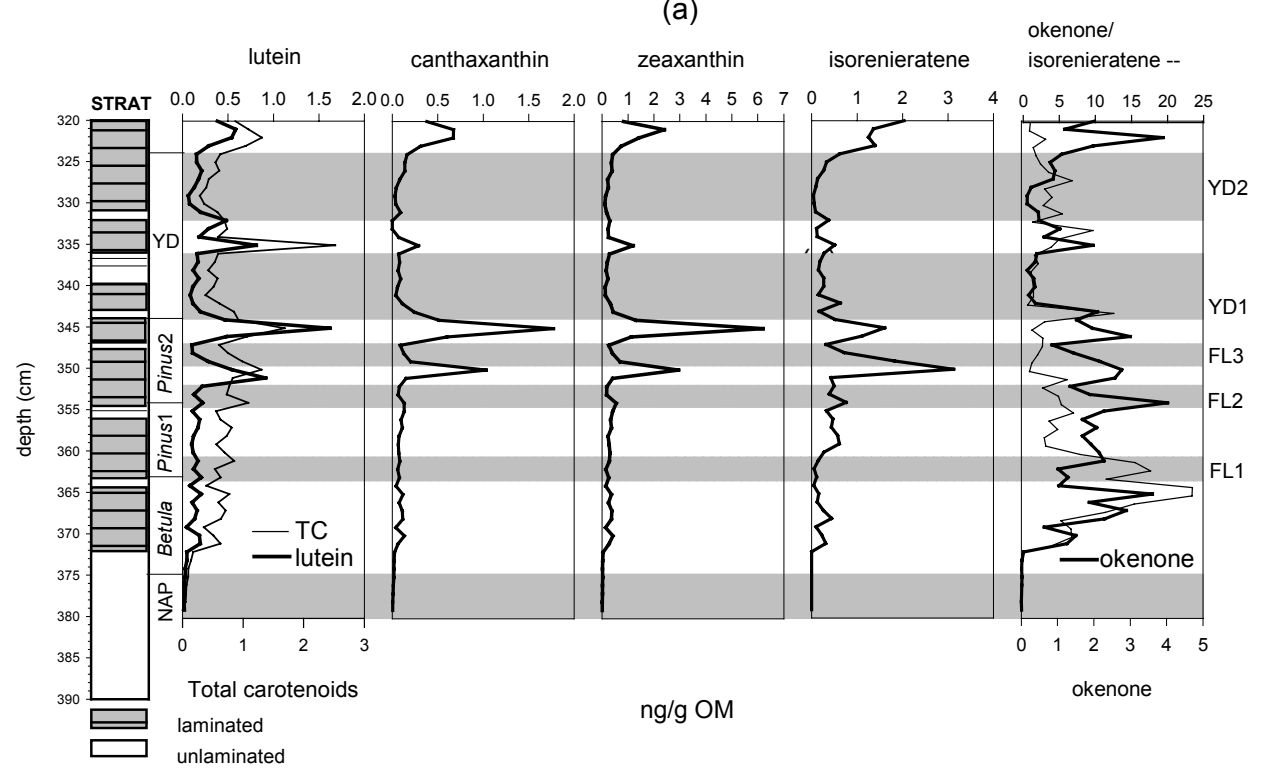

(b)

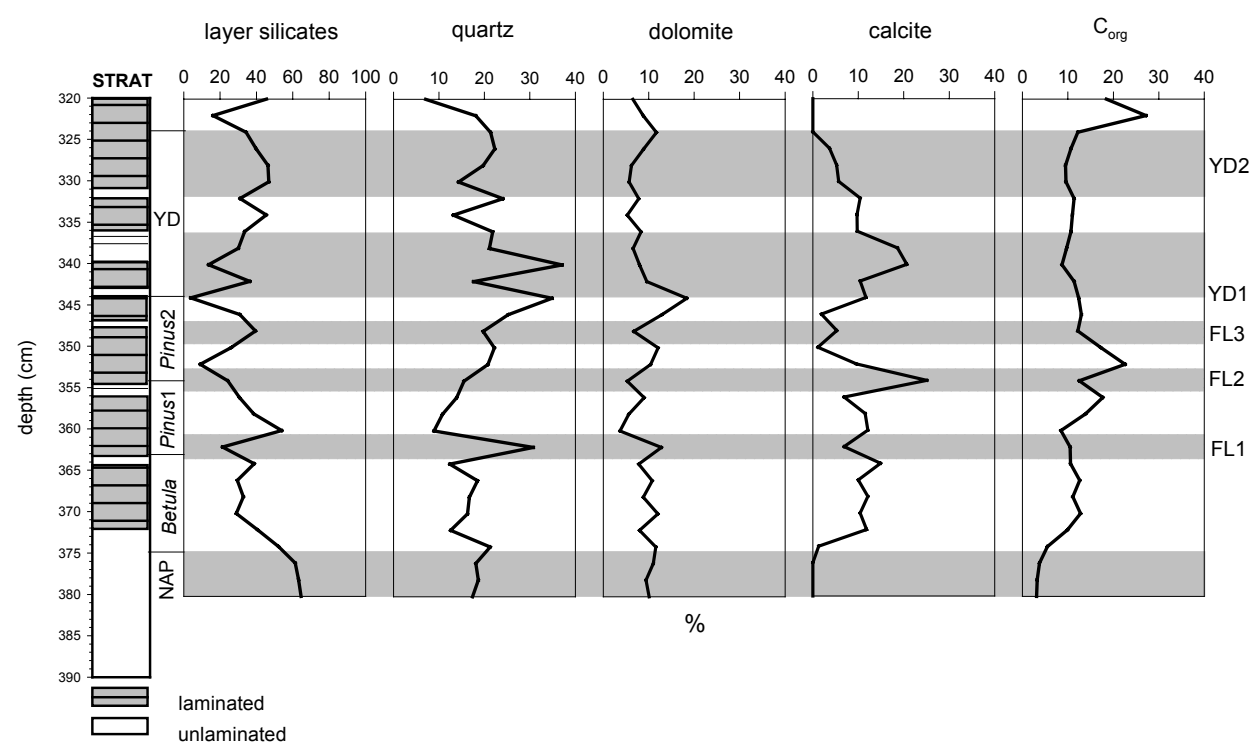

Fig. 5. (a) total carotenoids (TC) and selected pigments of the Längsee core (LG99), and (b) geochemistry (modified from Schmidt et al. 2002). The stratigraphy (STRAT), main pollen zones, and climate fluctuations (Lg-FL1-3) according to Schmidt et al. (2002) are shown. Cold phases of the late Pleniglacial NAP-rich period and the Younger Dryas (YD), as well as the climate fluctuations of the Lateglacial interstadial, are shaded.

Längsee to establish a stable stratification after icecover, as was suggested in the conceptual model.

\subsubsection{Lateglacial interstadial (375 to $343 \mathrm{~cm} ; 14,300$ to 13,900 cal. y BP)}

Slightly after the mass expansion of birch, at about 14,200 cal. BP, the onset of okenone and isorenieratene, produced by purple sulphur and green sulphur bacteria (Züllig 1986; Hodgson et al. 1998; Lami et al. 2000), indicate the development of an anoxic hypolimnion. Laminae formation started as a result of anoxic condi- tions. The relative increase of okenone, compared to isorenieratene, towards the top of the Betula-rich zone can be interpreted - as suggested by Brown et al. (1984) - as an increase in dissolved organic matter (DOM), and decrease in water transparency. The dominant $C$. praetermissa/quadrijuncta has, according to Wunsam et al. (1995), a TP-optimum of $24.5 \mu \mathrm{g} \mathrm{l}^{-1}$, and hence relates to mesotrophic conditions. This taxon probably reflects the higher concentration of nutrients in deciduous litter and a temperature increase that would enhance nutrient mineralization (Smol \& Boucherle 1985). 
The pollen-based division of the pine-dominated zone into two subzones (Schmidt et al. 2002) is supported by the diatom record. The older P. sylvestris-rich subzone 1 correlates with the diatom zone dominated by Cyclotella ocellata. This taxon in the Alpine calibration data set relates, according to Wunsam et al. (1995), to a TP-optimum of $38.0 \mu \mathrm{g} \mathrm{l}^{-1}$ (valves with 3 ocellae), although occurrences span a wide range from oligotrophic to hypertrophic conditions. Compared with the amount of total carotenoids, which are only slightly higher than during the former period, diatom-inferred total phosphorus, however, appears to be overestimated, probably due to the dominance of $C$. ocellata $(74 \%)$. This taxon was listed by Teubner (1995) as occurring in shallow lakes of the Berlin-Brandenburg area which are enriched in total phosphorus, total nitrogen, and dissolved reactive silica. C. ocellata occurrs also in running waters (Krammer \& Lange-Bertalot 1991). Silica and probably nitrogen which have favoured this taxon in Längsee have originated from the catchment. The increase in the abundance of $C$. ocellata in the Längsee core corresponds to that of layer silicates, indicating soil erosion. Soil erosion may have occurred during wet episods/seasons. This is supported by the form and size of calcite crystals which were observed in the Längsee varves. That indicate allochthonous sources and entrainment, probably during late autumn or spring (Schmidt et al. 2002), rather than in situ biogenic calcite precipitation (Niessen \& Sturm 1987; Raidt \& Koschel 1993). C. ocellata is known to bloom predominantly during late autumn and spring (Pantocsek 1901; Klee \& Steinberg 1987; Teubner 1995). In the case of the modern climate in Carinthia, heavy rain falls, as possible sources of catchment erosion and water level fluctuations, occurr during late autumn and spring due to the influence of Adriatic cyclones (Gressel 1976). In the area of Längsee (metereological station Drasendorf 1974-1992) the average snow-cover, another potential source for catchment erosion by meltwater fluxes, lasts 89 days (Honsig-Erlenburg 1995b). Sparse vegetation cover on the floor of Lateglacial $P$. sylvestris forests may not have completely prevented catchment erosion. The decline in the okenone to isorenieratene ratio indicates a decrease in DOM, which could be explained by the change in vegetation from broad-leafed Betula forests, rich in herbs, to Pinus sylvestris forests poor in undergrowth. Coniferous litter generally was assumed to be a relative poor source of nutrients for algal growth (Rodin \& Bazilevich 1967). Because of the discrepancy between vegetation cover (pine forests) and increased Di-TP, we conclude for Längsee that phosphorus may have originated mainly from the hypolimnion, due to temporarily mixing of the water column. Mixing was also suggested as the main source of phosphorus in the conceptual model of Längsee.

The younger Pinus sylvestris-rich subzone 2 is characterized by the expansion of Cyclotella comensis and
Stephanodiscus alpinus. These diatoms are found in Alpine lakes with oligotrophic to slightly mesotrophic conditions (Wunsam et al. 1995). Their abundance distribution results in a lower Di-TP-value when compared with the former $C$. ocellata-rich zone. Oligotrophic conditions indicate also the ocurrences of $C$. aff. plitvicensis. This taxon was described by Hustedt (1945) from the highly oligotrophic, and transparent, karstic lakes of Plitvice, Croatia. More frequent pollen of deciduous trees, especially Quercus, than during the Pinus sylvestris-rich subzone1 indicates an increase in summer temperature (Schmidt et al. 2002). The curve of isorenieratene culminated during the lower P. sylvestrisrich subzone 2. Together with okenone, it indicates strong oxygen depletion. Warming and drier climate conditions (see below) probably lowered nutrients originating from catchment erosion, and anoxic stability caused phosphorus trapping in the hypolimnion. Both processes can explain the low Di-TP values.

The peaks in okenone and isorenieratene correlate with those of lutein, zeaxanthin, and canthaxanthin. Lutein is a class-specific signature pigment found in Chlorophyceae and trachaeophytes, whereas zeaxanthin and canthaxanthin occurr in cyanobacteria (Züllig 1985, 1986; Hodgson et al. 1998; Lami et al. 2000); Additionally, canthaxanthin occurrs in invertebrate herbivores (Leavitt 1994).

There are several possibilities to explain the discrepancy between low Di-TP and increased pigment concentrations during the Pinus sylvestris-rich subzone 2. One possible explanation is that pigment concentrations may have originated from buoyancy regulated cyanobacteria. Since oscillaxanthin was, however, not detected, other cyanobacteria than the filamentous Planktothrix rubescens, specified as an eutrophic taxon (Feuillade et al. 1995), may have occurred. The lack of $P$. rubescens would fit to the finding of Schultze (1988/89) who did not observe oscillaxanthin before the time of sapropel formation in Längsee (which began with neolithic forest clearing, Schmidt et al. 1998). For the recent Längsee, Honsig-Erlenburg (2000) documented taxa of the genera Anabaena, Aphanocapsa, Chroococcus, Coelosphaerium, Microcystis, and Snowella. Bormans et al. (1999) suggested that buoyancy regulation in Anabaena and Microcystis depends much more on light than on nutrients. Another possible explanation is that picoplankton without buoyancy regulation was stratified within a water density gradient. According to Berger (1973), calcium-enriched waters are responsible for the formation of a density gradient in Längsee. A metalimnion can form in meromictic lakes when nutrient enrichment of the superficial waters ceases and its transperancy increases (Feuillade 1994). The highest phytoplankton biomasses in recent Längsee are observed between 8 and $12 \mathrm{~m}$ (Sampl et al. 1992; Honsig-Erlenburg 2000). 
Peaks in lutein during the Pinus sylvestris subzone 2 may have derived from blooms of Chlorophyceae (Honsig-Erlenburg 2000, mentions for the present Längsee the following genera: Oocystis, Pediastum, Willea, Golenkinia), or from debris of littoral terrestrial vegetation or from water plants which was deposited in the profundal. A productive metalimnion in the Lateglacial would have increased oxygen depletion in the hypolimnion. Peaks in okenone and isorenieratene, concurrent with those of algal groups indicating high lake productivity, were also observed for supposedly anoxic stages in the development of the central Italian crater lakes (Ryves et al. 1996; Lami et al. 1997).

The whole Pinus sylvestris-rich subzone 2 shows a marked decrease in calcite. Because the calcite decline is decoupled from pigments and Corg, which form distinct peaks, calcite dissolution was assumed. Calcite dissolution occurrs in lakes with bottom water anoxia due to enhanced bacterial respiration and mineralization processes lowering the $\mathrm{pH}$ of the hypolimnetic water; in addition, low calcite precipitation and accumulation rates can force calcite dissolution (Ohlendorf \& Sturm 2001). Berger (1973) assumed that in Längsee both biological and "physical precipitation" have contributed to the formation of meromixis. The latter he concluded from the influx of oversaturated hydrogen-carbonate waters originating from the calcareous underground. During the late glacial Pinus sylvestris-rich subzone 2 of Längsee, the epilimnion most probably was less productive than the metalimnion. Because of the warm and dry climate conditions, influx of calcium-enriched waters from the catchment might have been low. The calcite dissolution during this period corresponds with the conceptual model: $\mathrm{CO}_{2}$ oversaturation under strong hypolimnetic anoxia caused calcite dissolution, thus enhancing meromictic stability. Dissolution of only a small fraction (a few \%) of the precipitated calcite in the hypolimnion, according to Wüest et al. (1992), is sufficient to stabilize the water column. Calcite dissolution must have altered the proportions of the other minerals calculated as percentages of the total. Percentages of layer silicates were, however, at lowest during the Pinus sylvestris subzone 2 . This finding was explained by low weathering and erosional features.

In terms of climate, the culmination of meromixis concurrent with the pollen and sedimentological records are suggested as indicators of warm and dry summers coupled with cold winters poor in snow. These assumptions of continental climate conditions during the Pinus sylvestris-rich subzone 2, which was correlated with the Alleröd chronozone, are in agreement with the conceptual model.

\subsubsection{Younger Dryas (343 to $323 \mathrm{~cm}$ )}

The decrease in pigment concentrations during this biozone indicates lowering of primary productivity, presumably caused by lower water temperatures. This is indicated by the re-appearance of small, benthic Fragilaria taxa which occur, however, at lower abundances than during the late Pleniglacial period. Peaks in Di-TP mainly correspond to higher abundances of $C$. ocellata. The re-appearance of $C$. ocellata during the Younger Dryas supports the idea (see chapter 6.1.2) that this taxon is more competitive than other planktonic diatoms in turbulente waters with suspended minerogenic matter (silica, nitrogen?) or water column mixing (phosphorus). During the middle and upper part of the Younger Dryas, $C$. ocellata is accompanied by Asterionella formosa. A. formosa is known to be an opportunistic alga that responds rapidly to disturbance and nutrient enrichment, especially nitrogen (McKnight et al. 1990). A. formosa blooms mainly during early summer; secundary peaks were observed during autumn (Dokulil \& Skolaut 1986).

Okenone follows the decrease of the other pigments with a slight delay. The deepest part of the hypolimnion may have remained anoxic slightly longer. The following low amounts of okenone and isorenieratene indicate weak anoxic conditions. The changing preservation of laminae (Schmidt et al. 2002) supports the idea that the hypolimnion was temporarily oxygenated.

A longer lasting and thicker snow cover causing strong meltwater impacts from the catchment, cooler summer temperatures, and climate instability (see below), are supposed to be the main reasons for the lowering of the anoxic level during Younger Dryas - which is in accordance with the conceptual model.

\subsubsection{Younger Dryas/Holocene transition}

This period is characterized by the decoupling between peaks in $\mathrm{C}_{\text {org }}$ and all pigments, and calcite, which declines to non-detectable levels. Lake environmental conditions comparable with the younger $P$. sylvestris subzone 2 of the Lateglacial interstadial may have established. The absence of calcite in the Längsee core (LAENG1) during early Holocene was attributed by Schmidt et al. (1998) to calcite dissolution in a strongly reduced monimolimnion, as was suggested in the conceptual model.

\subsection{Impacts of late glacial climate fluctuations on lake stratification and trophy}

During the three minor climate fluctuations of the Lateglacial interstadial (Lg-FL1-3), changes in sediment composition indicate catchment erosion or sediment redeposition by lake level change (Schmidt et al. 2002). The corresponding decline in okenone and isorenieratene in the unlaminated layers may be due to a fluctuating oxygenation of the hypolimnion and/or pigment dilution during enhanced sediment accumulation.

If calcite dissolution is the reason for low calcite during Lg-FL3 (probably Gerzensee), the mechanism may be different from that discussed for strong meromixis of Alleröd time. Ohlendorf \& Sturm (2001) men- 
tion calcite dissolution in a Swiss high alpine lake which they relate to the formation of anoxia during periods with extended ice-cover. For the karstic Lake Vrana, Isle of Cres, Croatia, Schmidt et al. (2000) assumed that cold, $\mathrm{CO}_{2}$-oversaturated waters during a pluvial period with enhanced catchment runoff were responsible for calcite dissolution, explaining the relative increase in siliciclastics in the sediments. Since calcite dissolution is not the rule during the late glacial climate fluctuations of Längsee, this hydrological aspect would more likely explain calcite dissolution during the climate fluctuation of Lg-FL3.

During Younger Dryas, a slight increase of okenone in the middle of this biozone indicates a return to anoxic conditions. The following slight increase in total carotenoids and $\mathrm{C}_{\text {org }}$, and a short peak of St. minutulus resulting in a Di-TP increase, indicates a short-term increase in-lake productivity. Since these findings are concurrent with increased pollen of $P$. sylvestris and Betula as was observed by Schmidt et al. (2002), they may reflect a phase of moderate short-term climate amelioration. Since the marked peak in lutein at 331.5 $\mathrm{cm}$ at Längsee, however, corresponds with an unlaminated layer and a quartz peak, it may originate from allochthonous sources (possibly littoral leaf litter?) rather than reflecting increased productivity. The interphase of Younger Dryas climate amelioration at Längsee most likely correlates with minor variations in the oxygen isotope curves of Gerzensee, Switzerland (Eicher \& Siegenthaler 1976; Lotter et al. 2000), and GISP2 Greenland ice-core data (e.g. Stuiver et al. 1995). However, these minor variations are not significantly reflected in the pollen-inferred summer temperatures of the Gerzensee profile as reported by Lotter et al. (2000). Possible, the interphase of the Younger Dryas is better pronounced south of the Alps than at north.

The lower part of the Younger Dryas which is characterized by increased allochthonous influx (peaks in quartz and layer silicates) was assumed by Schmidt et al. (2002) to have been wetter than the upper part. Also the homogeneous, $2 \mathrm{~cm}$ thick, calcareous layer, which occurred at the lower part of the Younger Dryas, is of allochthonous origin. Benthic diatoms originating from the littoral, such as Amphora ovalis, support the idea of a redeposition of the homogeneous calcareous material from littoral lake marl, possible by changes in the water level.

Climate heterogeneity of the Younger Dryas reflected by the Längsee sediment core is supported by findings in the northern Adriatic. In a sediment profile from the Valun Bay, Isle of Cres, Croatia, the pollen distribution of P. mugo-types and foraminifers (Schmidt et al. 2001) support the climatic subdivision of the Younger Dryas of Längsee into three phases. Two phases of temperature decline, indicated by increased pollen of $P$. mugo-types at the beginning and the end of the Younger Dryas, are divided by a phase of climate amelioration. The lower part indicated freshwater incursions affecting the foraminifer distribution in the Bay of Valun. In Lake Vrana, close to the Bay of Valun, at $10,600{ }^{14} \mathrm{C}$ y $\mathrm{BP}$, the lake level increased again, suggesting higher humidity during the lower Younger Dryas (Schmidt et al. 2000).

During these climate fluctuations, and in accordance with the conceptual model, summer cool and wet periods, probably together with snow-melt episodes, appear at Längsee to have resulted in a lowering of the anoxic level or even in short periods with complete mixing.

\section{CONCLUSIONS}

- The unforested period of the late Pleniglacial is characterized by low primary production and a holomictic lake stage.

- The onset of anoxic conditions in the hypolimnion of Längsee, at about 14,300 cal. y BP follows the mass expansion of birch which indicates Lateglacial climate amelioration. Concurrent with the onset of anoxic conditions, laminae started to form. This anoxic, meromictic situation, indicated by high, though fluctuating, amounts of okenone, persisted throughout the Lateglacial interstadial.

- The sequence of diatom assemblages supports the pollen-based division of the Lateglacial interstadial into an early Betula-rich, and a subsequent Pinusrich, Lateglacial interstadial. The latter is divided into a less temperate, probably snow-rich, older Pinus sylvestris subzone 1 ( $<13,900$ cal. yrs. BP), and into a summer warmer and probably drier younger Pinus sylvestris subzone 2 prior to the Younger Dryas. Continental climate conditions and a more dense vegetation cover may have favoured meromictic stability during the latter subzone. This subzone probably correlates with the Alleröd chronozone in the sense of the NW German chronostratigraphy.

- Lamination is interrupted by unlaminated allochthonous sediment sections with lowered pigment concentrations. They were related to cool and wet (snow-rich?) climate fluctuations, coupled with enhanced allochthonous sediment accumulation and probably hypolimnetic oxygenation. Two of these oscillations of the Lateglacial interstadial have tentatively been correlated with the Aegelsee und Gerzensee oscillations in the Alps.

- Temperature decline, meltwater impacts from an extended snow-cover, and climate instability are assumed as the main reasons for the lowering of the anoxic level during the Younger Dryas. This period, however, was climatically heterogeneous. The lower part was probably wetter than the upper one. A slight return of increased anoxic conditions and primary productivity during an interphase of the Younger Dryas reflects a brief period of moderate climate amelioration. With the end of the Younger 
Dryas perturbations, meromictic stability established again.

The results of five significant parameters based on the conceptual model are summarized as following:

- Okenone and isorenieratene correspond closely to our assumption of a climate-driven meromixis.

- The trend of diatom-inferred epilimnetic total phosphorus (Di-TP) behaves as expected. To explain the discrepancy between pigment peaks and low epilimnetic Di-TP during enhanced meromixis of the Alleröd chronozone, however, the formation of a productive metalimnion is assumed.

- The calcite curve is more difficult to predict because calcite concentrations in the sediment depend on terrestrial and in-lake processes, such as redeposition, dissolution and precipitation. For calcite dissolution, two mechanism were proposed; the first one was related to increased $\mathrm{pCO}_{2}$ in the hypolimnion during enhanced anoxia of Alleröd time; the second one to $\mathrm{CO}_{2}$ enriched waters derived from the catchment during the climate oscillation of Gerzensee. Nontheless, calcite seems to decrease during prolonged warm periods (e. g. during Pinus subzone 2) and shows peak concentrations during or at the end of holomictic episodes.

- Siliciclastics, used as an indicator of physical weathering in the catchment, and the curve of organic carbon $\left(\mathrm{C}_{\text {org }}\right)$, mostly fit the concept quite well.

In sum, meromixis and trophy are closely related to late glacial climate forces. Our findings based on a multi proxy approach generally support the predictions of the conceptual model.

\section{ACKNOWLEDGMENTS}

The study was funded by the Austrian National Committee of the IGBP, the Austrian Academy of Sciences, and the Ministry of Sciences and Traffic (IGBP12/97/20/99) We want to thank L. Schulz and W. Honsig-Erlenburg (Kärntner Institut für Seenforschung, Klagenfurt) for providing unpublished data; R. Kurmayer for various limnological discussion and $\mathrm{K}$. Teubner for help in HPLC analyses; J.P. Smol and A. Lami for critically reading the manuscript; H. Höllerer and J. Knoll for technical help, and N. Crosbie for improving the English.

\section{REFERENCES}

Battarbee, R.W. 1986. Diatom analysis. In: Berglund, B.E. (Ed.), Handbook of Holocene Palaeoecology and Palaeohydrology. Wiley, Chichester, 527-570.

Battarbee, R.W., S. Juggins, F. Gasse, N.J. Anderson, H. Bennion, N.G. Cameron, D.B. Ryves, C. Pailles, F. Chalie \& R. Telford. 2001. European Diatom Database (EDDI). An Information System for Palaeoenvironmental Reconstruction. ECRC Environmental Change Research Centre, University College London, Research Report No. 81: 83 pp.

Bennion, H., P.G. Appleby \& G.L. Phillips. 2001. Reconstructing nutrient histories in the Norfolk Broads, UK: im- plications for the role of diatom-total phosphorus transfer functions in shallow lake management. J. Paleolim., 26: 181-204.

Berger, F. 1973. Einige physikalische und hydrochemische Beobachtungen am Längsee. In: Arbeitsbericht über die limnologische Exkursion 1972 zum Längsee. Carinthia II, 163/83: 332-336.

Bormans, M., B.S. Sherman \& I.T. Webster. 1999. Is buoyancy regulation in cyanobacteria an adaptation to exploit separation of light and nutrients? Mar. Freshwat. Res., 50: 897-906.

Borrego, C.M. \& L.J. Garcia-Gil. 1994. Separation of bacteriochlorophyll homologues from green photosynthetic sulfur bacteria by reversed-phase HPLC. Photosynthesis Research, 41: 157-163.

Brown, S.R., H.J. McIntosh \& J.P. Smol. 1984. Recent palaeolimnology of a meromictic lake: fossil pigments of photosynthetic bacteria. Verh. int. Ver. Limnol., 22: 357360.

Dokulil, M. \& C. Skolaut. 1986. Succession of phytoplankton in a deep stratifying lake: Mondsee, Austria. Hydrobiologia, 138: 9-24.

Douglas, M.S.V. \& J.P. Smol. 1999. Freshwater diatoms as indicators of environmental change in the High Arctic. In: Stoermer, E.F. \& J.P. Smol (Eds), The Diatoms: Applications for the Environmental and Earth Sciences. Cambridge University Press, Cambridge: 227-244.

Eicher, U. \& U. Siegenthaler. 1976. Palynological and oxygen isotope investigations on Late Glacial sediment cores from Swiss lakes. Boreas, 5: 109-117.

Feuillade, J. 1994. The cyanobacterium (blue-green alga) $O s-$ cillatoria rubescens D.C. Arch. Hydrobiol. Beih., 41: 7793.

Feuillade, M., J. Dominik, J-C. Druart \& J-L. Loizeau. 1995. Trophic status evolution of Lake Nantua as revealed by biological records in sediment. Arch. Hydrobiol. 132/3: 337-362.

Findenegg, I. 1935. Limnologische Untersuchungen im Kärntner Seengebiet. Int. Revue ges. Hydrobiol., 32: 369-423.

Findenegg, I. 1937. Holomiktische und meromiktische Seen. Int. Revue ges. Hydrobiol. Hydrog., 35: 586-610.

Findenegg, I. 1947. Der Längsee. Eine limnologische Untersuchung. Carinthia II, 56: 77-93.

Findenegg, I. 1953. Kärntner Seen naturkundlich betrachtet. Carinthia II, SH 15: 1-101.

Frey, D.G. 1955. Längsee. A history of meromixis. Mem. Ist. ital. Idrobiol., Suppl. 8: 125-135.

Frey, D.G. 1956. Die Entwicklungsgeschichte des Längsees in Kärnten. Carinthia II, 146/66: 5-12.

Gressel, W. 1976. Wetter und Klima in Kärnten. In: Die Natur Kärntens 2. Klagenfurt, 269-311.

Harmsworth, R.V. 1984. Längsee: A geochemical history of meromixis. Hydrobiologia, 108: 219-231.

Hodgson, D.A., S.W. Wrihgt, P. Tyler \& N. Davies. 1998. Analysis of fossil pigments from algae and bacteria in meromictic Lake Fidler, Tasmania and its application to lake management. J. Paleolimnol., 19: 1-22.

Honsig-Erlenburg, M. 2000. Das Phytoplankton im Längsee. Fachbereichsarbeit in Biologie am BG/BRG St. Veit an der Glan: 28pp.

Honsig-Erlenburg, W. \& N. Schulz. 1989. Der Längsee und seine fischereiliche Situation (Teil 1). Österreichs Fischerei, 42/10: 245-253.

Honsig-Erlenburg, W. 1995a. Die Gewässer. In: Das Buch von St. Georgen am Längsee. (Herausgeber: Gemeinde St. Georgen am Längsee): 32-44.

Honsig-Erlenburg, W. 1995b. Das Klima und das Wetter. In: Das Buch von St. Georgen am Längsee. (Herausgeber: Gemeinde St. Georgen am Längsee): 28-30.

Hustedt, F. 1945. Diatomeen aus Seen und Quellgebieten der Balkan-Halbinsel. Arch. Hydrobiol., 40/4: 867-973. 
Jeffrey, S.W., R.F.C. Mantoura \& S.W. Wright. 1997. Phytoplankton pigments in oceanography: guidelines to modern methods. UNESCO Publishing.

Klee R. \& C. Steinberg 1987. Kieselalgen bayerischer Gewässer. Inform. Bayer. Landesamt für Wasserwirtschaft 4/87, München.

Krammer, K. \& H. Lange-Bertalot. 1991. Bacillariophyceae, 3. Teil: Centrales, Fragilariaceae, Eunotiaceae. Süßwasserflora von Mitteleuropa, G. Fischer Verlag , Stuttgart, Jena, Band 2/3, 1-576

Lami, A.; P. Guilizzoni, D.B. Ryves, V.J. Jones, A. Marchetto, R.W. Battarbee, C.A. Belis, R. Bettinetti, M. Manca, P. Comoli, A. Nocentini \& L. Langone. 1997. A late glacial and holocene record of biological and environmental changes from the crater lake Albano, central Italy: an interdisciplinary European project (PALICLAS). Water Air Soil Pollut., 99: 601-613.

Lami, A., P. Guilizzoni \& A. Marchetto. 2000. High resolution of fossil pigments, carbon, nitrogen and sulphur in the sediment of eight European Alpine lakes: the MOLAR project. In: Lami, A., N. Cameron \& A. Korhola (Eds), Paleolimnology and ecosystem dynamics at remote European Alpine lakes. J. Limnol., 59, Suppl. 1: 15-28.

Leavitt, P.R., P.R. Sanford, S.R. Carpenter \& J.F. Kitchell. 1994. An annuall fossil record of production, planktivory and piscivory during whole-lake manipulations. J. Paleolimnol., 11: 133-149.

Line, J.M., C.J.F. ter Braak \& H.J.B. Birks. 1994. WACALIB version 3.3 - a computer program to reconstruct environmental variables from fossil diatom assemblages by weighted averaging and to derive sample specific errors of prediction. J. Paleolimnol., 10: 147-152.

Litt, T., A. Brauer, T. Goslar, J. Merkt, K. Balaga, H. Müller, M. Ralska-Jasiewiczowa, M. Stebich \& J.F.W. Negendank. 2001. Correlation and synchronisation of Lateglacial continental sequences in northern central Europe based on annually-laminated lacustrine sediments. Quaternary Science Reviews, 20: 1233-1249.

Löffler H., 1973. Die Entwicklung der Meromixis in Klopeiner See and Längsee. Carinthia II, 163: 331-377.

Löffler, H., 1975. The onset of meromictic conditions in Alpine lakes. In: Suggate, R.P and Cresswell, M.M. (Eds), R. Soc. N.Z., Wellington, 211-214.

Lotter, A.F., U. Eicher \& U. Siegenthaler. 1992. Late-Glacial climate oscillations as recorded in Swiss lake sediments. $J$. Quater. Sci., 7: 187-204.

Lotter, A.F., H.J.B. Birks, U. Eicher, W. Hofmann, J. Schwander \& L. Wick. 2000. Younger Dryas and Allerød summer temperatures at Gerzensee (Switzerland) inferred from fossil pollen and cladoceran assemblages. Palaeogeography Palaeoclimatology Palaeoecology, 159: 349361 .

Mantoura, R.F.C. \& C.A. Llewellyn. 1983. The rapid determination of algal chloropyll and carotenoid pigments and their breakdown products in natural waters by reversephase high-performance liquid chromatography. Analytica Chimica Acta, 151: 297-314.

McKnight, D.M., R.L. Smith, J.P. Bradbury, J.S. Baron \& S. Spaulding. 1990. Phytoplankton dynamics in three Rocky Mountain lakes, Colorado, U.S.A. Arctic Antarctic and Alpine Research, 22: 264-274.

Niessen, F. \& M. Sturm. 1987. Die Sedimente des Baldeggersees (Schweiz) - Ablagerungsraum und Eutrophierungsentwicklung während der letzten 10 Jahre. Arch. Hydrobiol., 108: 365-383.

Ohlendorf, C. \& M. Sturm. 2001. Precipitation and Dissolution of Calcite in a Swiss High Alpine Lake. Arctic, Antarctic, and Alpine Research, 33/4: 410-417.

Pantocsek, J. 1901. Die Kieselalgen oder Bacillarien des Balaton. Budapest. In: Resultate der wissenschaftlichen
Erforschung des Balatonsees. II Band, 2. Comission ung. geograph. Ges: 1-112.

Raidt, H. \& R. Koschel. 1993. Variable morphology of calcite crystals in hardwater lakes. Limnologica, 23/1: 85-89.

Rodin, L.E. \& N.I. Bazilevich. 1967. Production and mineral cycling in terrestrial vegetation. Oliver and Boyd, Edinburgh.

Ryves, D.B., V.J. Jones, P. Guilizzoni, A. Lami, A. Marchetto, R.W. Battarbee, R. Bettinetti \& E.C. Devoy. 1996. Late Pleistocene and Holocene environmental changes at Lake Albano and Lake Nemi (central Italy) as indicated by algal remains. In: P. Gulizzoni \& F. Oldfield (Eds), Palaeoenvironmental Analysis of Italian Crater Lake and Adriatic Sediments. Mem. Ist. ital. Idrobiol., 55: 119-148.

Sampl, H., N. Schultz, G. Deisinger, W. Honsig-Erlenburg, E. Zechner \& E. Grund. 1992. Kärntner Seenbericht. Veröffentlichungen des Kärntner Institutes für Seenforschung 7, Abteilung 15 Umweltschutz, Klagenfurt: 472 pp.

Sampl, H., L. Schulz \& M. Mairitsch. 2001. Kärntner Seenbericht. Veröffentlichungen des Kärntner Institutes für Seenforschung, 15: $58 \mathrm{pp}$.

Schmid, H. \& H.B. Stich. 1995. HPLC-analysis of algal pigments: comparison of columns, column properties and eluents. J. Appl. Phycol., 7, 487-494.

Schmidt, R., S. Wunsam, U. Brosch, J. Fott, A. Lami, H. Löffler, A. Marchetto, H.W. Müller, M. Prazákova \& B. Schwaighofer. 1998. Late and post-glacial history of meromictic Längsee (Austria), in respect to climate change and anthropogenic impact. Aquat. Sci., 60: 56-88.

Schmidt, R., J. Müller, R. Drescher-Schneider, R. Krisai, K. Szeroczyńska \& A. Barič. 2000. Changes in lake level and trophy at Lake Vrana, a large karstic lake on the Island of Cres (Croatia), with respect to palaeoclimate and anthropogenic impacts during the last approx. 16,000 years. $J$. Limnol., 59(2): 113-130.

Schmidt, R., N. Pugliese, J. Müller, K. Szeroczyńska, D. Bogner, R. Melis, Ch. Kamenik, A. Barič \& D.L. Danielopol. 2001. Palaeoclimate, vegetation and coastal lake development, from the Pleniglacial until early Holocene, in the northern Adriatic Valun bay (Isle of Cres, Croatia). Il Quaternario, Italian Journal of Quaternary Sciences, 14(1): 61-78.

Schmidt, R., Ch. van den Bogaard, J. Merkt \& J. Müller. 2002. A new Lateglacial chronostratigraphic tephra marker for the south-eastern Alps: The Neapolitan Yellow Tuff (NYT) in Längsee (Austria) in the context of a regional biostratigraphy and palaeoclimate. Quaternary International, 88/1: 45-56.

Schultze, E. 1988/89. Fallstudien zur Paläolimnologie. Geologija, 31/32: 437-516.

Schultze, E. \& R. Niederreiter. 1990. Paläolimnologische Untersuchungen an einem Bohrkern aus dem Profundal des Mondsees (Oberösterreich). Linzer Biol. Beitr., 22: 231235.

Schulz, N. \& K. Kanz. 1984. Neue Tiefenkarte des Längsees (Kärnten, Österreich). Carinthia II, 174/94: 381-386.

Schulz, L., R. Fresner, G. Kerschbaumer \& M. Mairitsch. 1998. Exkursionsbericht: Kärntner Seen. Deutsche Ges. für Limnologie (DGL) und Int. Ges. für Limnologie (SIL) (Hsgb.): 59 pp.

Smol, J.P. 1988. Paleoclimate proxy data from freshwater arctic diatoms. Verh. int. Ver. Limnol., 23: 837-844.

Smol, J.P. \& M.M. Boucherle. 1985. Postglacial changes in algal and cladoceran assemblages in Little Round Lake, Ontario. Arch. Hydrobiol., 103/1: 25-49.

Sommaruga, R. \& R. Psenner. 1997. Ultraviolet radiation in a high mountain lake of the Austrian Alps: Air and underwater measurements. Photochemistry \& Photobiology, 65: 957-963.

Stuiver, M., P.M. Grootes \& T.F. Braziunas. 1995. The GISP $2 d^{18} \mathrm{O}$ climate record of the past 16,500 years and the 
role of the sun, ocean, and volcanoes. Quaternary Research, 44: 341-354.

Teubner, K. 1995. A light microscopical investigation and multivariate statistical analyses of heterovalvar cells of Cyclotella-species (Bacillariophyceae) from lakes of the Berlin-Brandenburg region. Diatom Research, 10/1: 191205.

Wright, S., S.W. Jeffrey, R.F.C. Mantoura, C.A. Llewellyn, T. Bjornland, D. Repeta \& N. Welschmeyer. 1991. Improved HPLC method for the analysis of chlorophylls and carotenoids from marine phytoplankton. Mar. Ecol. Prog. Ser., 77: 183-196.

Wüest, A., W. Aeschbach-Haertig, H. Baur, M. Hofer, R. Kipfer \& M. Schurter. 1992. Density structure and tritiumhelium age of deep hypolimnetic water in the northern basin of Lake Lugano. Aquat. Sci., 54: 205-218.

Wunsam, S., 1995. Diatomeen (Bacillariophyceae) als Bioindikatoren in Alpenseen. Transferfunktionen zwischen

Received: August 2001

Accepted: February 2002
Diatomeen und Umweltvariablen (ALPTROPH). Diss. Formal- und Naturwiss. Fak. Wien: 147 pp.

Wunsam, S. \& R. Schmidt. 1995. A diatom-phosphorus transfer function for Alpine and pre-alpine lakes. Mem. Ist. ital. Idrobiol., 53: 85-99.

Wunsam, S., R. Schmidt \& R. Klee. 1995. Cyclotella-taxa (Bacillariophyceae) in lakes of the Alpine region and their relationship to environmental variables. Aquat. Sci., 57/4: 360-386.

Züllig, H., 1985. Pigmente photoautotropher Bakterien in Seepigmenten und ihre Bedeutung für die Seenforschung. Schweiz. Z. Hydrobiol., 47(2): 87-126.

Züllig, H. 1986. Carotenoids from plankton and photosynthetic bacteria in sediments as indicators of trophic changes in Lake Lobsigen during the last 14,000 years. Hydrobiologia, 143: 315-319.

Züllig, H., 1989. Role of carotenoids in lake sediments for reconstructing trophic history during the late Quaternary. $J$. Paleolimnol., 2: 23-40. 